\title{
THE EFFECTS OF ORGANIZATIONAL BRAND EQUITY ON EMPLOYMENT BRAND EQUITY AND RECRUITMENT OUTCOMES
}

\author{
JAKUB SOVINA \\ CHRISTOPHER J. COLLINS \\ Department of Human Resource Studies \\ School of Industrial and Labor Relations \\ Cornell University \\ Ithaca, NY 14853-3901
}

\section{INTRODUCTION}

Despite the importance of the first stage of recruitment, there has been limited research regarding the factors that influence job seekers' decisions during this stage or how firms can systematically impact those factors (Barber, 1998). There is some evidence that employment brand equity (Cable \& Turban, 2001; Collins \& Stevens, 2002) affect job seekers' attraction to and intentions to apply to organizations. While employment brand equity seems to be an important concept, the real effects of brands on recruitment outcomes have not been fully investigated yet. First, researchers need to clearly identify the dimensions of employment brand equity (Barber, 1998). Second, researchers need to explore how employment brand equity is created. While there is some evidence that recruitment activities affect job seekers' perceptions of employment brands (e.g. Collins \& Stevens, 2002; Han \& Collins, 2002), very little attention has been given to the potential effects of organizational brand building activities (e.g. corporate marketing and advertising). Barber (1998) proposed that there might be spillover effects of organizational marketing on job seekers' perceptions of the organization as an employer. The purpose of this paper is to identify potential dimensions of employment brand equity, and to empirically investigate the effects of organizational brand-building activities on employment brand equity and recruitment outcomes.

\section{THEORY AND HYPOTHESES}

\section{The Marketing Concepts of Organizational Brand Equity}

Aaker $(1991,1996)$ defined brand equity as the positive or negative effects that the brand has on consumers' preferences and purchasing decisions of a product or service marketed under this brand. According to Keller's (1991) definition, brand equity consists of two independent factors. The first dimension of brand equity is brand awareness, which represents the strength of a consumer's memory record for the brand (Keller, 1991). Greater awareness increases consumers' ability to identify a brand and the likelihood that the brand will be included in the consideration set (Aaker, 1996; Rossiter \& Percy, 1987). The second dimension of brand equity is brand associations, defined as the memory nodes linked to the corresponding brand node in consumer's memory, which contain the meaning that the brand has for consumers (Keller, 1991). Aaker $(1991,1996)$ argued that brand associations facilitate the process of consumer choice consumers are more likely to choose those brands for which they hold strong, positive associations. There are two key categories of associations - attributes (specific beliefs about the 
product, service, or organization) and attitudes (general feelings toward the product, service, or organization).

\section{Employment Brand Equity and Related Concepts}

An organization's efforts to recruit job seekers are similar in many ways to the organization's efforts to attract consumers to purchase their products or services (Cable \& Turban, 2001). Specifically, job seekers and consumers both develop positive or negative perceptions about companies and jobs based on their exposure to messages communicated by an organization (Collins \& Stevens, 2002). Thus, the marketing literature on brand equity can be useful for helping to understand how job seekers develop beliefs about organizations as employers (Cable \& Turban, 2001; Collins \& Stevens, 2002).

Recruitment literature has traditionally focused on the applicant's reactions to different jobs, different recruitment practices, or a combination of the two. This line of research has also utilized the marketing concept of organizational image. However, while image has been found to significantly affect job seekers' response to organizational recruitment (Belt \& Paolillo, 1982; Gatewood et al., 1993; Turban \& Greening, 1997), most of these studies only measured the overall favorability of this image. Only the most recent studies (e.g. Highouse et al., 1999; Collins \& Stevens, 2002, Han \& Collins, 2002) have begun to analyze the underlying dimensions of employment image. Further, Collins and colleagues (Collins \& Stevens, 2002; Han \& Collins, 2002) applied a marketing model of brand equity to define the concept of employment brand equity and included image as a component of this larger construct.

Based on the consumer brand equity literature, Collins and Stevens (2002) identified two dimensions of employment brand equity: awareness and associations. They defined awareness as the level of familiarity that job seekers hold regarding an organization. As with consumers, awareness of the company will increase the likelihood that the company will be part of the final decision set when job seekers identify job opportunities (Collins \& Stevens, 2002). As with the brand equity literature discussed above, Collins and Stevens (2002) argued that brand associations consist of both attitudes and perceived attributes. They defined attitudes as the level of general positive feelings that job seekers hold toward an organization and perceived attributes as job seekers' beliefs about specific aspects of the job and work environment of the organization.

In a review of the literature on recruitment, Barber (1998) suggested that there are a large number of different job and organizational attributes that job seekers consider when evaluating employers. Therefore, it seems practical to define broader valid and reliable categories of attributes when examining the effects of organizational attributes. To identify these broader dimensions, we drew from the psychological contract literature (e.g. Rousseau, 1996, 2001). The psychological contract between individuals and organizations has been defined as subjective "expectations about the reciprocal obligations that compose an employee-organization exchange relationship" (Morrison \& Robinson, 1997:228). Two types of psychological contracts may exist, defining a one-dimensional continuum (Rousseau, 1999). A transactional contract is usually short-term with focus on extrinsic values and rewards. A relational contract is typically defined as long-term in nature with a focus on intrinsic values and rewards. However, Milkovich \& Neumann (2002) argued that job seekers will hold perceptions about both transaction and relational aspects of a job. In this paper, we examined the two components of the psychological contract separately, thus defining a two-dimensional space. 


\section{Organizational Brand Building Activities and Employment Brands}

Marketing research has suggested that adverting is one of the most important firm activities for affecting corporate brand equity (Gabbet, 1981; Aaker, 1996). For example, research has shown that advertising is positively related to consumers' awareness (Gabbet, 1981), attitudes (Cobb-Walgren et al., 1995), and associations (Boulding et al., 1994). However, additional research suggests that marketing activities other than advertising also affect brand equity. For example, researchers have shown that market performance, social responsibility, and differentiation are positively related to the dimensions of corporate brand equity (e.g. Upshaw, 1995; Dowling, 2001).

While advertising and other marketing communications are known to affect brand equity of the company as a producer of products or services, these activities might also have positive effects on employer brand equity. For example, Barber (1998) proposed that organizational communication and marketing that affect general organizational brand equity may also have spillover effects on perceptions of the organization as an employer. Media visibility and advertising were also found to be significantly correlated with job seekers' intentions to apply (e.g. Fombrun \& Shanley, 1990). Thus, we predict that there would be spillover effects such that there will be a positive relationship between an organization's brand-building activities and its employment brand equity.

Hypothesis 1a: Organization's brand-building activities will be positively related to its employment brand equity.

Recruitment and marketing literature provides some evidence that organizational marketing activities and advertising in particular have positive impact on perceptions about organizational image (e.g. Dowling, 1988; Dacin \& Smith, 1994) and that these activities also positively affect employment image (e.g. Fombrun \& Shanley, 1990; Gatewood et al., 1993). Following the proposition of spillover effects (Barber, 1998; Cable \& Turban, 2001) from organizational image onto employment image, we expect that the effects of organizational marketing activities on employment brand equity will be mediated by organizational brand equity through transfer of knowledge, i.e. brand extension (Aaker, 1990).

Hypothesis 1b: Organization's brand-building activities will positively affect job seekers' perceptions of employment brand through their effects on general brand equity.

\section{Brand Equity Dimensions and Intentions to Apply}

In the early phase of recruitment, one of the key outcomes is a job seeker's intention to apply (Barber, 1998). Job seekers in this phase of recruitment usually do not have perfect information about potential employers. They form their perceptions about organizations based on the information that is available to them, for example their perceptions of organizational and employment images and other components of both brand equities. Then they use these perceptions to make decisions about how to react to recruitment activities of companies (Cable \& Turban, 2001). Previous employment branding and employment image studies have provided evidence that job seeker's perceptions of an organization as employer are positively related to job seeker's intention to apply (e.g. Collins \& Stevens, 2002; Gatewood et al., 1993). This study will investigate the combined effects of organizational and employment brand equities on job seekers' intentions in the early stage of recruitment. We expect that perceived organizational 
brand equity would serve as potential source of information for job seekers during their decisionmaking process. Following Barber's (1998) notion of spillover effects and the theory of brand extensions (e.g. Aaker, 1990), we expect to find that organizational brand equity affects job seekers' intentions to apply and that this relationship is mediated by employment brand equity. Hypothesis 2: Organizational brand equity will be positively related to job seekers' intentions to apply through its effects on employment brand equity.

\section{METHOD}

We paired data from publicly available data sources and surveys of student job seekers to test our hypotheses. First, we collected data on brand building activities for six FT Global 500 organizations from publicly available sources. In order to separate the effects of corporate brand building efforts from those due to recruitment, we selected companies that do not recruit on the university campus from which the student sample was drawn. The companies that participated in the study were from two different industries and differed in terms of brand recognition and total number of employees. Second, we collected measures of job seeker perceptions through a surveys of 141 undergraduate and graduate students from two colleges at a large Northeastern university in US. Each student supplied their answers to survey questions about three companies from a randomly assigned industry. Students were asked to evaluate multiple companies to more closely replicate the complexity of their actual job search experience (see Collins \& Stevens, 2002). Because each student rated multiple companies in the survey, we used within-subject regression to analyze the data.

\section{Measures}

Organizational brand-building activities. As identified above, our measures of brand building activities were collected through secondary sources of data. Based on a review of marketing literature and analysis of a number of measures, we used a four-item aggregate measure of corporate visibility. This measure consisted of Business Week Best 100 Global Brands ranking (recoded for positive loading) as an indicator of overall brand strength; the number of trademarks registered with the US Patent and Trademark office as a measure of two organizational attributes - innovativeness and market activity in terms of number of original products and services; Selling, general, and administrative costs (SG\&A) in fiscal year 2000 to measure the investment in marketing and advertising activities; and Fortune Most Admired Companies overall rating as a measure of general reputation. All measures were first converted to z-scores and then combined in a linear fashion to form a single scale. The combined measure of corporate brand building activities showed good reliability $(\alpha=.79)$.

Measures of Perceived Organizational Image. Two dimensions of organizational image were collected through the student survey: (1) organizational brand awareness and (2) organizational brand associations. We measured organizational brand awareness, defined as familiarity with the organization, as a 2-item scale $(\alpha=.86)$ adapted from Han and Collins (2002). We developed an eight-item scale to measure organizational brand associations based on a review of the marketing literature on organizational brand equity (e.g. Lassar, Mittal \& Sharma, 1995; Aaker, 1996b; Mackay, 2001). Using a principal component factor analysis with Varimax rotation, two components (eigenvalues $>1.0$ ) were identified. Consistent with marketing literature, we summarized the two resulting scales as Perceived Reputation $(\alpha=.79)$, and Perceived Value $(\alpha$ 
$=.82$ ). Together, these two measures explained $64.4 \%$ of the overall item variance. We calculated aggregate indicators averages of respective items for each scale. Individual items for each scale can be obtained from the authors.

Measures of perceived employer brand equity. The association and attitude dimensions of employment brand equity were collected through the student survey. Measures of associations were based on the psychological contract literature (e.g. Rousseau, 2001; Herriot, Manning \& Kidd, 1997) and recruitment research (e.g. Powell, 1991; Barber \& Roehling, 1993). We developed two 5 -item scales to reflect the distinction between the relational and transactional dimensions of psychological contract. These measures showed good reliability $(\alpha=.84$ for relational and $\alpha=.80$ for transactional). Together, these two measures explained $59.64 \%$ of the overall item variance. We measured general brand attitudes as attraction to the company using a 3 -item scale $(\alpha=.81)$ adapted from Collins and Stevens (2002).

Intentions to apply. Intentions to apply were measured using a 2 -item scale $(\alpha=.94)$ adapted from Collins \& Stevens (2002). This measure has been shown to correlate highly with actual application decisions (Collins \& Stevens, 2002).

\section{RESULTS AND DISCUSSION}

\section{Hypotheses 1a-b: Organization's Brand-Building Activities and Employment Brand.}

Hypothesis 1a predicted that organizational brand-building activities have positive effects on job seekers' perceived employment brand equity. Organizational brand-building activities were significantly related to all three dimensions of employment brand equity (Transactional Attributes: $\mathrm{R}^{2}=.05 ; \beta=.26 ; \mathrm{p}<.001 ;$ Relational Attributes: $\mathrm{R}^{2}=.04 ; \beta=.22 ; \mathrm{p}<.001$; Attraction: $\mathrm{R}^{2}=.07 ; \beta=.33 ; \mathrm{p}<.001$ ). Thus, there was support for Hypothesis 1a, but the overall effect sizes were small in nature - organizational brand-building activities explained less than $7 \%$ of the variances of the individual dimensions of employment brand equity.

Hypothesis $1 \mathrm{~b}$ predicted that the relationship between brand-building activities and employment brand equity would be mediated by job seekers' perceptions of organizational brand equity. We followed the three-step procedure outlined by Baron and Kenny (1986) to test for mediation. First, we demonstrated that there was a significant relationship between organization's brand-building activities and employment brand equity (see Hypothesis 1a). Second, we tested the relationship between brand-building activities and respondents' perceptions of organizational brand equity. Brand-building activities were significantly related to organizational brand equity (familiarity $\beta=.53 ; \mathrm{p}<.001$, perceived reputation $\beta=.42 ; \mathrm{p}<$ .001 ; perceived value $\beta=.34 ; \underline{p}<.001$ ). Third, we assessed the relationship between brandbuilding activities employment brand equity while controlling for organizational brand equity. Organizational brand building activities were no longer significantly related to the three measures of employment brand equity when the measures of organizational brand equity were added to the equation. Further, the measures of organizational brand equity were related to each of the measures of employment brand equity. Overall, we found support for hypothesis $1 b$.

Therefore, our findings suggested that job seekers form their perceptions of employment image of organizations, in part, based on their general perceptions of organizations. Thus, strong organizational brands can provide a competitive advantage in the labor market and potentially reduce advertising costs in the early stage of recruitment by helping to establish the initial image of an organization in the eyes of job seekers. Strong marketing mixes help organizations to 
achieve a more positive overall corporate image which in turn may lead potential job seekers to view the company as a good place to work. Although there was a positive relationship between marketing activities and employment brand equity, the effects were relatively small in size. It is likely that this relationship is small in size because marketing is only one of the sources of information that job seekers use to form their perceptions about employers. It is also possible that the size of the effects were somewhat reduced by the rough measures of marketing activities used in this study.

\section{Hypothesis 2: Organizational Brand Equity and Intentions to Apply}

Hypothesis 2 predicted that employment brand equity would serve as a mediator for the effects of organizational brand equity on intentions to apply. Again, a three-step analysis was used to test the mediation (Baron \& Kenny, 1986). First, all three components of organizational brand equity were significant predictors and together predicted almost $15 \%$ of the total variance in intentions to apply (Familiarity $\beta=.20, \underline{p}<.001$; Perceived Value $\beta=.10, \underline{p}=.04$; Perceived Reputation $\beta=.23, \underline{p}<.001)$. Second, we found that each of the three measures of employment brand equity was related to our measures of organizational brand equity. Finally, we found that two of the organizational brand equity measures were no longer related to intentions to apply when the measures of employment brand equity were added to the equation. We also found that the relationship between familiarity and intentions to apply dropped significantly when the measures of employment brand equity were added to the equation. Finally, in the overall equation, we found that two of the three measures of employment were significantly related to intentions to apply. Thus we found partial support for Hypothesis 2.

The results imply that organizations with strong organizational brands are more likely to have strong employment brands and may be able to generate larger pools of applicants. The hypothesis of mediation was, however, not supported for familiarity, which appeared to be partially mediated. This suggests that for an individual there is little difference between awareness as a consumer in the product market, and awareness as a job seeker in the labor market. Further, our findings suggest that those companies with little or no corporate brand awareness may need to build recognition about their company as an employer to attract a large pool of applicants. Thus, companies with weaker organizational brands may need to invest more in recruitment and build their employment brand equity directly. By the design of the study, we were not able to determine the impact of corporate marketing activities above those of recruitment actions. Therefore, future research needs to focus on a comparison of the effects of both recruitment and marketing activities on recruitment outcomes.

Overall, the results of this study suggest that the concepts of branding from marketing literature combined with the literature on psychological contracts is a useful lens for understanding job seekers' perceptions and intentions during the initial phase of recruitment. From the academic standpoint, this study contributes to the body of recruitment literature by adding additional understanding about how firms attract potential employees and by identifying specific dimensions of employment brand equity. From the practitioner standpoint, these findings may help recruitment managers to improve their understanding of the factors that are important for potential job candidates during their job search process. The findings also suggest that staffing practitioners need to understand the possible impact of their corporate brand equity.

\section{REFERENCES AVAILABLE FROM THE AUTHORS}

